\title{
Kasper Fisker: Det Kriminalpræventive Styresystem
}

Hans Reitzels Forlag, 2020, 1. udgave (306 sider). ISBN 978-87-412-7529-1

Kasper Fiskers mål med boken avsløres allerede før man åpner den. Tittelen Det kriminalpræventive styresystem og baksideteksten røper en ambisjon om å systematisere kriminalitetsforebyggende arbeid gjennom å presentere en metodisk ramme og en forebyggingsteknisk modell for systematisk kriminalitetsforebyggende arbeid. Som Fisker skriver i forordet, presenterer boken en idealmodell som skal gjøre arbeidet enklere for de som jobber med kriminalitetsforebygging.

Til tross for at disse ambisjonene peker i retning av en praktisk, rent ut sagt teknisk, tilnærming til kriminalitetsforebygging, hviler boken på et faglig, til dels kritisk, fundament. Fisker lar risikoen for kontraproduktive effekter av kriminalitetsforebyggende tiltak løpe som en rød tråd gjennom boken. Fiskers ambisjon synes med andre ord å være å kombinere en praktisk og teknisk tilnærming til kriminalitetsproblemer og forebyggende tiltak med en årvåkenhet for mulige kontraproduktive effekter. Dette har vært mangelvare i denne type litteratur. Stort sett nøyer forfattere seg med å presentere forskjellige kriminalitetsforebyggende tiltak, samt evalueringer og til nød forskning som enten konstaterer positiv, svak eller manglende effekt på kriminaliteten. At kriminalitetsforebyggende tiltak skal kunne ha kontraproduktive effekter har stort sett vært noe forskere uten ambisjoner om å bidra med praktiske løsninger har forfektet. I Fiskers bok knyttes risiko for kontraproduktive effekter direkte til de praktiske og tekniske aspektene av modellen. Dette er uvanlig og et eksempel til etterfølgelse.

Boken er delt i 3 deler og 13 kapitler, og er på 306 sider. Allerede i kapittel 1 viser Fisker hvordan hans bok skiller seg fra andre bøker om kriminalitetsforebygging. Han utfordrer mantraet om at forebygging alltid er bra. Forebygging er ikke bra når kostnadene overstiger nytten, og heller ikke når forebygging bidrar til problemforsterkning. Utfordringen blir da: Hvordan kan vi vite det - i forkant?

Del 1 har tittel Problemer. Her plasserer Fisker kriminalitetsforebygging som en gren av anvendt kriminologi, der kriminalitetsproblemet danner det naturlige utgangspunkt for forebyggingstiltak. Et viktig mål med problemanalysen blir å identifisere om man står overfor et problem som kan forebygges, hvem som er problemeier, og hva som i så fall er beste løsning på problemet. Fisker retter i denne delen søkelyset mot selve problemdiagnostikken som mange hopper bukk over, særlig fordi mange ofte begynner med et kriminalitets- 
forebyggende tiltak som man ønsker å ta i bruk, snarere enn en grundig BOGANMELDELSE analyse av hvilket problem man står overfor.

Å finne kriminalitetens årsaker er imidlertid ingen enkel oppgave. Kriminologiens historie viser med all tydelighet at et kriminalitetsproblem kan defineres, forstås og forklares på mange ulike måter og nivåer. For å unngå årsaksbegrepet, foreslår Fisker i stedet å bruke «kriminogene faktorer» og «risikofaktorer», fordi det peker mer mot korrelasjon enn kausalitet. Samtidig er han påpasselig med å advare mot troen på at risikofaktorer kan brukes til prediksjon, og han advarer også mot inngripende tiltak basert på uklare risikofaktorer, fordi det vil kunne føre til overdosering og kontraproduktive effekter. I stedet vil han bruke allmenne risikofaktorer til å avdekke potensiell sårbarhet, ikke potensiell risiko. Denne forskjellen mellom risiko og sårbarhet er viktig, det får betydning for tiltakene man velger - intervensjon eller støtte. Fisker viser her en beundringsverdig bekymring for å bruke avdekkede risikofaktorer til intervensjon. Han anbefaler ressursorienterte tiltak for å minimere faren for stigmatisering og problemforsterkning.

Del 2 har tittel Forebyggelse. Denne delen begynner med det Fisker kaller de fem læresetninger (s. 126). Her viser Fisker igjen sin kritiske tilnærming til feltet, ved å understreke at alle tiltak er forbundet med risiko, eller «behandlingsrisiko», som han kaller det; den kan være høy, hvis kriminalitetsrisikoen er lav, og lav, hvis kriminalitetsrisikoen er høy. Både underdosering og overdosering av tiltak og intervensjoner er problematisk. Underdosering vil være uproduktivt og ha liten eller ingen effekt, mens overdosering vil være kontraproduktivt og medføre en utilsiktet negativ effekt. Disse negative effektene behøver ikke bety mer kriminalitet, det kan også være snakk om andre negative effekter, alt fra økt frykt til marginalisering, konfliktforsterkning og mindre tillit. Overdosering kan innebære at man utpeker personer til å være i risikogruppen uten at de nødvendigvis er det, at man utsetter primærgrupper for sekundærforebyggende tiltak, eller sekundærgrupper for tertiærforebyggende tiltak.

For å øke sannsynligheten for at kriminalitetsforebyggende tiltak skal ha en positiv effekt og liten eller ingen negativ effekt, må man søke proporsjonalitet $\mathrm{i}$ intervensjonen. Dette høres tilforlatelig ut, men etter å ha lest en mengde innføringsbøker i kriminalitetsforebygging, er min klare erfaring at de aller fleste ignorerer denne viktige dimensjonen ved kriminalitetsforebyggende arbeid. De fleste nøyer seg med å beskrive ulike tiltak og så vise til enkeltstudier som viser enten en positiv eller ingen effekt på kriminaliteten. En grundig gjennomgang av kontraproduktive effekter og andre problematiske aspekter ved kriminalitetsforebygging er stort sett fraværende. Et viktig unntak fra Skandinavia, er Ingrid Sahlins bok Brottsprevention som begrepp og samhällsfenomen (2000).

Fisker kritiserer videre den utbredte forestillingen om at jo tidligere innsats, jo bedre. Eksemplene han viser til er primært hentet fra personrettede og sosiale tiltak, noe som kanskje gjør kapittelet mer effektivt, fordi de er 
så utbredte i dansk og skandinavisk kriminalitetsforebyggende tiltak. Jeg BOGANMELDELSE savner allikevel eksempler fra situasjonelle tiltak. Fisker kunne også utnyttet sin kritiske og uavhengige posisjon i enda større grad og diskutert andre kontraproduktive effekter enn problemforsterkning. Men alt i alt er kapittel 6 for meg bokens beste og viktigste kapittel - samt det mest nyskapende. De som arbeider med kriminalitetsforebygging, vil muligens finne andre deler av boken vel så nyttig. Men også for dem vil jeg mene at kapittel 6 er et viktig kapittel for å se egen virksomhet i en større sammenheng.

Resten av del 2 fortsetter så med å praktisere læresetningene i konkret kriminalitetsforebyggende virksomhet. Her viser Fisker at man før man starter med kriminalitetsforebyggende tiltak bør vurdere om problemet kan forebygges - med andre ord om man ved å intervenere øker sannsynligheten for positiv effekt, samtidig som sannsynligheten for ingen eller negativ effekt reduseres. Intervensjonsrisikoen må ikke overstige kriminalitetsrisikoen, med andre ord: se opp for overdosering! Eksemplene han gir på kriminalitetsforebyggende tiltak er personfokusert. Det ville vært interessant å se hvordan Fisker ville anlagt en situasjonell tilnærming til eksemplene han nevner.

Del 3 har tittel Organisering. Fisker tar utgangspunkt i hvordan dagens kriminalitetsforebyggende arbeid er organisert i Danmark, og hvem som er de sentrale aktørene. Organisasjonskartet tegnes både vertikalt og horisontalt. Plasseringen - og aktørene - sier noe om hvor man antar kriminalitetsproblemet ligger, og slik blir plasseringen selvforsterkende - både på aktørene, hvordan man forstår kriminalitetsproblemet og de kriminalitetsforebyggende tiltakene disse så ser og iverksetter.

Fisker er selv inne på dette s. 235, der han peker på at de som arbeider kriminalitetsforebyggende i fremtiden må regne med en utvidelse av målgruppen for tiltak; ikke lenger primært eller kun ungdommer, men alle i samfunnet, en utvidelse av oppgavene; ikke lenger primært eller kun ungdomskriminalitet og rusrelaterte problemer, men også andre kriminalitetsproblemer, og dermed også en utvidelse av samarbeidspartnere; ikke lenger primært eller kun skole og sosialvesenet, men i større grad også private og andre sivilsamfunnsaktører.

I et interessant etterskrift peker Fisker på at kriminalitetsforebygging har sterke bånd til politikken - tiltakene er ofte både symbolske og systemlegitimerende mer enn rent faglige og problemløsende. Hans ambisjon er å øke forutsetningene for samfunnsnytte og redusere forutsetningene for skadevirkninger innenfor det kriminalitetsforebyggende felt gjennom sin modell. Jeg er ikke riktig person til å vurdere om selve modellen er nyttig for de som i sitt daglige arbeid vil ha bruk for den type systematisk tilnærming som boken tilbyr. Jeg savner imidlertid en mer kritisk drøfting av forebyggingsbegrepets og -virksomhetens grenser, for eksempel i kapittel 12. Fisker sondrer her mellom proaktiv, reaktiv og operativ forebygging. Denne begrepsbruken og modellene som utvikles som følge av disse er etter mitt syn både 
unødvendig kompleks og nærmest uforståelig. Fisker går langt i å bruke et BOGANMELDELSE forebyggingsbegrep som favner alt - og dermed ingenting, men han er ikke alene. I kriminalpolitikken ser vi et nærmest grenseløst forebyggingsbegrep. Det kan være politisk opportunt, men faglig sett er jeg usikker på om vi skal omfavne det.

Fiskers bok representerer et kjærkomment tilskudd til skandinaviskspråklig litteratur om kriminalitetsforebygging, både i teori og i praksis. Bokens klare styrke er dens analytiske og kritiske tilnærming til kriminalitetsproblemet og kriminalitetsforebygging. Som nevnt er alt for mye litteratur ignorant overfor kontraproduktive aspekter ved kriminalitetsforebyggende virksomhet.

Jeg er mindre begeistret for det oppskriftsmessige ved boken. Her tar jeg imidlertid forbehold om at jeg ikke befinner meg i bokens målgruppe. Jeg vil allikevel oppfordre Fisker til å utvide det forebyggende repertoar ut over de tiltak og aktører som allerede fyller feltet, samtidig som jeg etterlyser en mer kritisk holdning til forebyggingsbegrepets og -systemets grenser.

\section{Litteratur:}

Sahlin, Ingrid (2000): Brottsprevention som begrepp og samhällsfenomen. Lund: Arkiv förlag.

Heidi Mork Lomell, Professor

Universitetet i Oslo 